\title{
Analysis of Polyphenolic Content and Antioxidant Activity of Four Dark Skin Grapes
}

\author{
Yanqiu Shen ${ }^{1, \#}$, Wanling Zhang ${ }^{1, \#}$, Xiaohan Wei ${ }^{1}$, Guihong Zhou ${ }^{3}$, Hui Xia ${ }^{2}$, Dong Liang ${ }^{2, \text { a }}$ \\ ${ }^{1}$ College of Horticulture, Sichuan Agricultural University, 611130 Chengdu, Sichuan, China \\ ${ }^{2}$ Institute of Pomology and Olericulture, Sichuan Agricultural University, 611130 Chengdu, Sichuan, China \\ ${ }^{3}$ Science-Technology \& Agriculture-Livestock Bureau of Wenchuan county, 623000 Aba Tibetan and Qiang Autonomous Prefecture, \\ Sichuan \\ ${ }^{\#}$ Co-first author; ${ }^{\text {aCCrresponding author }}$
}

\begin{abstract}
The polyphenolic of grape skins, pulps and seeds are potential source of natural antioxidant, which are receiving increased attention. In the present work, the total phenolics content (TPC), total flavonoids content (TFC), total flavanols content (TFAC), total anthocyanins content (TMAC) and antioxidant activity (DPPH, ABTS and FRAP) in different tissues of 4 table grapes cultivated in Chengdu plain, south of China, were investigated. In present study, expect TMAC was not be detected in seeds, and our results showed that seeds were the highest in polyphenolic content and antioxidant activity followed by skins, and then pulp. Besides, 'Fenghou' is richer in polyphenolic content than other three cultivars. Hence, 'Fenghou' extracts possesses higher free radical scavenging ability.
\end{abstract}

\section{Introduction}

The grape (Vitis vinifera L.) is one of the most important and widely cultivated fruit crop around the world with an annual production of more than 75 million tonnes (FAOSTAT 2013). As one of the most popular fruits today, grape is also well-known for an excellent source of antioxidants, such as flavonoids, polyphenol, pigments and others [1, 2]. All these antioxidant compounds have strong antioxidant functions that enable them to scavenge free radicals or suppressing formation of free radicals in vitro and in vivo [3, 4]. It has been considered that a network of bioactive compounds with different physicochemical properties may function in a synergistic way to protect human from chronic diseases, cardiovascular diseases, cancer and delaying aging [5].

The aim of the present study was to evaluate the antioxidant composition and capacity of the various parts including skins, pulps and seeds of 4 table grape cultivars grown in Chengdu plain, south of China. This study was carried out to provide sufficient experimental evidence for the antioxidant activity and potential for further development and utilization of these cultivars.

\section{Materials ad methods}

\subsection{Plant material}

The study was performed on grape (Vitis vinifera L.) with a bilateral cordon training system on 2018, in a commercial table grape vineyard located in the territory of Yong-an town (N30²4', E103 $\left.59^{\prime}\right)$, Chengdu, China. Vine rows were cultivated under the plastic rain shelter and planting density was $3 \mathrm{~m}$ between rows and $1 \mathrm{~m}$ between vines. Fertilizer additions, pest control, and other vineyard operations were conducted according to local practices.

Grape samples of $2 \mathrm{~kg}$ for each cultivar were harvested manually from different plants at full mature stage. Grapes berry were brought to the laboratory immediately. Seeds, skins and pulps were carefully separated manually.

\subsection{Method}

Seeds, skin and pulps were used to detect polyphenolic and antioxidant activity. The TPC of all tissues were determined by using the Folin-Ciocalteu method [6]. The TFC was determined according to the method of Jia et al. [7]. p-DMACA method was used to detect TFAC [8]. The TMAC was estimated by the $\mathrm{pH}$ differential method [9]. The DPPH (2,2-diphenyl-1-picrylhydrazyl) scavenging activity was determined based on an assay modified by Brandwilliams et al. [10]. The ABTS (2,2azino-bis (3-ethylbenzothiazoline-6-sulfonic acid) diammonium salt) assay was based on the method from Re et al.[11]. The FRAP (ferric reducing antioxidant power) was measured by following a procedure derived from Benzie and Strain [12].

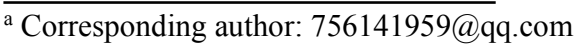




\subsection{Statistical analysis}

All analysis was performed in triplicate. The mean and standard error of means were calculated. Data were analysed by using SPSS 22.0 by one way analysis of variance (ANOVA). A multiple comparison procedure of the treatment means was performed by Duncan Test. Significance of the differences was defined as $P<0.05$.

\section{Results}

\subsection{Cultivars characteristics}

As shown in Table 1, the skin of all the four cultivars have deep colour. 'Guanghui' possesses purple appearance, and 'Summer Black' was black, both 'Purple Globe' and 'Fenghou' have dark purple skin. Besides, there were seeds detected in 'Guanghui' and 'Fenghou', but no seeds in 'Summer Black' and 'Purple Globe'.

Table 1. Characteristics of four dark skin grape Cultivars

\begin{tabular}{ccc}
\hline & & \\
Grape cultivar & Skin color & Seeds (Y/N) \\
& & \\
\hline Guanghui & Purple & Y \\
Summer Black & Black & $\mathrm{N}$ \\
Purple Globe & Dark Purple & $\mathrm{N}$ \\
Fenghou & Dark purple & $\mathrm{Y}$ \\
\hline
\end{tabular}

Y, seeds; N, no seeds.

\subsection{TPC in different grape cultivars and tissues}

The TPC of extracts measured by the Folin-Ciocalteu method was shown in Table 2. There were significant differences $(p<0.05)$ between the total content of phenolic compounds in different grape cultivars and tissues. The TPC in different grape skins ranged from 570.4 to $823.3 \mathrm{mg} \mathrm{GAE} / \mathrm{kg} \mathrm{FW}$. 'Fenghou' contained the highest contents of total phenolics whereas the lowest values for that parameter were found in 'Summer Black'. The TPC ranged from 76.7 to $101.1 \mathrm{mg} \mathrm{GAE} / \mathrm{kg} \mathrm{FW}$ in the pulp and from 5466.6 to $5725.1 \mathrm{mg} \mathrm{GAE} / \mathrm{kg} \mathrm{FW}$ in the seeds (Table 2). 'Fenghou' grape contained the highest contents of total phenolics in the skins and seeds, 'Purple Globe' in pulp, whereas the lowest values were measured from 'Summer Black'. Comparison with TPC in different tissues, seeds had highest content, followed by skins, while TPC in pulps was absolutely less than that of skin and seeds.

Table 2.TPC in different grape cultivars and tissues

\begin{tabular}{cccc}
\hline Grape cultivar & \multicolumn{3}{c}{ TPC (mg GAE/kg FW) } \\
\cline { 2 - 4 } & Skin & Pulp & Seed \\
\hline Guanghui & $600.1 \pm 29.2 \mathrm{bc}$ & $86.3 \pm 5.4 \mathrm{~b}$ & $5466.6 \pm 177 \mathrm{~b}$ \\
Summer & $570.4 \pm 16.4 \mathrm{c}$ & $83.5 \pm 2.6 \mathrm{~b}$ & $\mathrm{ND}$ \\
Black & $630.2 \pm 30.2 \mathrm{~b}$ & $101.1 \pm 5.5 \mathrm{a}$ & $\mathrm{ND}$ \\
Purple Globe & $823.3 \pm 23.5 \mathrm{a}$ & $76.7 \pm 1.4 \mathrm{c}$ & $5725.1 \pm 186 \mathrm{a}$ \\
Fenghou &
\end{tabular}

$\mathrm{ND}$, not detected; GAE, gallic acid equivalent;

Values are means \pm SD values of three replicates.
Different letters indicate significant difference at $p<0.05$ by Duncan's test.

\subsection{TFC in different grape cultivars and tissues}

TFC and TPC differed significantly, while exhibiting the same rank order among grape cultivars extracts (Table 3 ). TFC in different grape skins ranged from 1055.0 to $1380.7 \mathrm{mg} \mathrm{RE} / \mathrm{kg} \mathrm{FW}$, and 'Fenghou' contained the highest contents of total flavonoids. TFC in pulps ranged from 225.8 to $263.2 \mathrm{mg} \mathrm{RE} / \mathrm{kg} \mathrm{FW}$, 'Fenghou' and 'Summer Black'contained the highest contents of total flavonoids whereas the lowest values for that parameter were found in 'Crimson'. TFC in seeds ranged from 14144.1 to $15796.2 \mathrm{mg} \mathrm{RE} / \mathrm{kg} \mathrm{FW}$, and 'Fenghou' contained the highest. Among all cultivars, seeds had the highest TFC, followed by those from skins and pulps.

Table 3.TFC in different grape cultivars and tissues

\begin{tabular}{cccc}
\hline \multirow{2}{*}{$\begin{array}{c}\text { Grape } \\
\text { cultivar }\end{array}$} & Skin & Pulp & Seed \\
\cline { 2 - 4 } Guanghui & $1055.0 \pm 60.7 \mathrm{~b}$ & $227.8 \pm 15.4 \mathrm{bc}$ & $14144.1 \pm 466.8 \mathrm{~b}$ \\
$\begin{array}{c}\text { Summer } \\
\text { Black }\end{array}$ & $1094.3 \pm 57.3 \mathrm{~b}$ & $267.1 \pm 35.2 \mathrm{a}$ & ND \\
Purple & $1088.9 \pm 48.4 \mathrm{~b}$ & $225.8 \pm 15.5 \mathrm{bc}$ & ND \\
Globe & $1380.7 \pm 63.2 \mathrm{a}$ & $263.2 \pm 36.4 \mathrm{a}$ & $15796.2 \pm 398.3 \mathrm{a}$ \\
\hline Fenghou &
\end{tabular}

ND, not detected; RE, gallic acid equivalent;

Values are means \pm SD values of three replicates.

Different letters indicate significant difference at $p<0.05$ by Duncan's test.

\subsection{TFAC in different grape cultivars and tissues}

Flavanols are important phenolic compounds in grapes. Here, values for TFAC in the peel ranged from 150.1 to $220.1 \mathrm{mg} \mathrm{CE} / \mathrm{kg} \mathrm{FW}$ (Table 4). Skin of 'Fenghou' contained the highest TFAC while the lowest was found in 'Guanghui' and 'Summer Black'. TFAC in seeds ranged from 2030.9 to $2460.3 \mathrm{mg} \mathrm{CE} / \mathrm{kg} \mathrm{FW}$, and was the highest for 'Fenghou' seeds extract (Table 4). Pulps extract had lower TFAC than that of skins and seeds, pulps extract of 'Fenghou' was the highest (15.5 \pm 0.2 $\mathrm{mg} \mathrm{CE} / \mathrm{kg} \mathrm{FW}$ ) and that of 'Guanghui' was the lowest.

Table 4. TFAC in different grape cultivars and tissues

\begin{tabular}{cccc}
\hline Grape & \multicolumn{3}{c}{ TFAC (mg CE/kg FW) } \\
\cline { 2 - 4 } cultivar & Skin & Pulp & Seed \\
\hline Guanghui & $150.5 \pm 15.7 \mathrm{c}$ & $11.3 \pm 2.7 \mathrm{c}$ & $2030.9 \pm 120.2 \mathrm{~b}$ \\
$\begin{array}{c}\text { Summer } \\
\text { Black }\end{array}$ & $150.6 \pm 14.3 \mathrm{c}$ & $13.2 \pm 1.1 \mathrm{~b}$ & $\mathrm{ND}$ \\
$\begin{array}{c}\text { Purple } \\
\text { Globe }\end{array}$ & $144.0 \pm 11.2 \mathrm{~cd}$ & $12.6 \pm 1.1 \mathrm{bc}$ & $\mathrm{ND}$ \\
Fenghou & $220.1 \pm 15.8 \mathrm{a}$ & $15.5 \pm 0.2 \mathrm{a}$ & $2460.3 \pm 130.1 \mathrm{a}$
\end{tabular}

$\mathrm{ND}$, not detected; CE, catechin equivalent.

Values are means \pm SD values of three replicates.

Different letters indicate significant difference at $p<0.05$ by Duncan's test. 


\subsection{TMAC in different grape cultivars and tissues}

TMAC was very important and decided the grape colour. TMAC of skin and pulp were high in four dark peel cultivars (from 2355.3 to $3754.4 \mathrm{mg} \mathrm{C} 3 \mathrm{GE} / \mathrm{kg} \mathrm{FW}$ ), (Table 5). The TMAC was particularly low in 'Italia' and 'Rosario Bianco', due to these cultivars possessing white peels. In pulps, the order of TMAC same as that in skins, while the values were lower remarkably than skins. Nevertheless, TMAC in the seeds of all tested cultivars were not calculated because seeds may not contain anthocyanins.

Table 5. TMAC in different grape cultivars and tissues

\begin{tabular}{cccc}
\hline \multirow{2}{*}{$\begin{array}{c}\text { Grape } \\
\text { cultivar }\end{array}$} & \multicolumn{3}{c}{ TMAC (mg C3GE/kg FW) } \\
\cline { 2 - 4 } Guanghui & $2355.3 \pm 74.1 \mathrm{~d}$ & $90.1 \pm 3.1 \mathrm{c}$ & NA \\
Summer & $3754.4 \pm 82.5 \mathrm{a}$ & $140.4 \pm 2.2 \mathrm{a}$ & ND \\
$\begin{array}{c}\text { Black } \\
\text { Purple }\end{array}$ & $3327.1 \pm 81.6 \mathrm{~b}$ & $52.3 \pm 7.4 \mathrm{~d}$ & ND \\
$\begin{array}{c}\text { Globe } \\
\text { Fenghou }\end{array}$ & $3524.8 \pm 48.8 \mathrm{~b}$ & $99.1 \pm 2.6 \mathrm{~b}$ & NA
\end{tabular}

ND, not detected; NA, not available; and C3GE, cyanidin 3glucoside equivalent.

Values are means \pm SD values of three replicates.

Different letters indicate significant difference at $p<0.05$ by Duncan's test.

\subsection{Antioxidant activity in different grape cultivars and tissues}

The DPPH, ABTS and FRAP values of skins, pulps and seeds fractions of 4 table grapes were presented in Table 6,7 and 8 on the basis of $\mu \mathrm{mol}$ Trolox equivalent (TE) $/ \mathrm{g}$ FW.

In the skin, Trolox equal antioxidant capacity values measured by DPPH ranged from 31.8 to 38.1 ; ABTS ranged from 51.7 to 59.8; and by FRAP, from 1443.5 to 1683.6. In the seeds, antioxidant activity of DPPH, ABTS and FRAP ranged from 123.4 to 130.3, from 232.5 to 252.4 and from 4058.6 to 4182.0 , respectively. However, the DPPH, ABTS and FRAP values of pulp ranged separately from 16.4 to $17.8,15.1$ to 16.1 and from 204.6 to 227.3 .

In parallel to the antioxidant activity data of 4 dark skin grape cultivars determined by DPPH, ABTS and FRAP assay, seeds were the highest in antioxidant activity followed by skins. Pulp fractions of grape showed the lowest antioxidant activity (Table6, 7, 8). In the skin, DPPH, ABTS and FRAP in 'Fenghou' were higher than other three cultivars. Nonetheless, DPPH, ABTS and FRAP in seeds and pulp had not significant correlation with skin colour in all tested cultivars. The results indicated that the seeds of tested grape cultivars were the best source of antioxidants content and activity, followed by skins and then pulps of grapes.
Table 6. DPPH free radical scavenging capacity in different grape cultivars and tissues

\begin{tabular}{cccc}
\hline \multirow{2}{*}{ Grape cultivar } & \multicolumn{3}{c}{ DPPH $(\mu \mathrm{mol} \mathrm{TE} / \mathrm{g} \mathrm{FW})$} \\
\cline { 2 - 4 } & Skin & Pulp & Seed \\
\hline Guanghui & $31.8 \pm 1.0 \mathrm{c}$ & $16.4 \pm 0.8 \mathrm{~b}$ & $123.4 \pm 1.6 \mathrm{~b}$ \\
Summer Black & $32.6 \pm 0.6 \mathrm{c}$ & $16.4 \pm 1.1 \mathrm{~b}$ & ND \\
Purple Globe & $35.2 \pm 0.8 \mathrm{~b}$ & $16.5 \pm 0.5 \mathrm{~b}$ & ND \\
Fenghou & $38.1 \pm 1.2 \mathrm{a}$ & $17.8 \pm 0.6 \mathrm{aa}$ & $130.3 \pm 4.3 \mathrm{a}$ \\
\hline
\end{tabular}

$\mathrm{ND}$, not detected; TE, trolox equivalent.

Values are means \pm SD values of three replicates.

Different letters indicate significant difference at $p<0.05$ by Duncan's test.

Table 7. ABTS free radical scavenging capacity in different grape cultivars and tissues

\begin{tabular}{cccc}
\hline \multirow{2}{*}{ Grape cultivar } & \multicolumn{3}{c}{ ABTS $(\mu \mathrm{mol} \mathrm{TE} / \mathrm{g} \mathrm{FW})$} \\
\cline { 2 - 4 } & Skin & Pulp & Seed \\
\hline Guanghui & $51.7 \pm 2.3 \mathrm{bc}$ & $15.1 \pm 0.7 \mathrm{c}$ & $252.4 \pm 17.4 \mathrm{a}$ \\
Summer Black & $52.7 \pm 1.8 \mathrm{~b}$ & $15.4 \pm 1.5 \mathrm{bc}$ & ND \\
Purple Globe & $55.5 \pm 2.8 \mathrm{~b}$ & $15.6 \pm 0.5 \mathrm{~b}$ & ND \\
Fenghou & $59.8 \pm 2.2 \mathrm{a}$ & $16.1 \pm 1.1 \mathrm{a}$ & $232.5 \pm 14.3 \mathrm{~b}$ \\
\hline
\end{tabular}

TE, trolox equivalent.

Values are means \pm SD values of three replicates.

Different letters indicate significant difference at $p<0.05$ by Duncan's test.

Table 8. FRAP free radical scavenging capacity in different grape cultivars and tissues

\begin{tabular}{cccc}
\hline Grape & \multicolumn{3}{c}{ FRAP $(\mu \mathrm{mol}$ TE/g FW $)$} \\
\cline { 2 - 4 } cultivar & Skin & Pulp & Seed \\
\hline Guanghui & $1443.5 \pm 107 \mathrm{c}$ & $217.3 \pm 12.1 \mathrm{~b}$ & $4058.6 \pm 367.4 \mathrm{~b}$ \\
Summer & $1575.7 \pm 73.4 \mathrm{~b}$ & $204.6 \pm 11.7 \mathrm{c}$ & ND \\
Black & & & \\
Purple & $1504.5 \pm 59.8 \mathrm{bc}$ & $208.2 \pm 14.7 \mathrm{c}$ & ND \\
Globe & $1683.6 \pm 79.5 \mathrm{a}$ & $227.3 \pm 11.1 \mathrm{a}$ & $4182.0 \pm 320.5 \mathrm{a}$ \\
Fenghou & &
\end{tabular}

TE, trolox equivalent.

Values are means $\pm \mathrm{SD}$ values of three replicates.

Different letters indicate significant difference at $p<0.05$ by Duncan's test.

\section{Discussion}

Yilmaz et al. demonstrated the pulps, seeds and skins of 22 grape varieties contained rich total phenolic contents grown in the Marmara region of Turkey [13]. In study by $\mathrm{Xu}$ et al., grape pomace from four Virginia-grown grape varieties had rich total phenolic, total flavonoid, total anthocyanin, tannins and condensed tannins [14]. In the present study, expect TMAC was not be detected in seeds, we also observed that skins, pulps and seeds contained rich TPC, TFC, TFAC and TMAC in 4table grape cultivars grown in Chengdu plain, China. Thus, above works indicated grape is wonderful fruit to produce polyphenol from fresh or process in skins, pulps and seeds.

Fruits are complex biological systems and contain a multiplicity of antioxidants. Therefore, there is no general single method, which can inspect accurately all antioxidants in fruits. Until now, several methods have been developed to evaluate the total antioxidant activity of different plants tissues. Among them, DPPH, ABTS 
and FRAP are the representative methods frequently used in various researches [15]. In a study by Katalinic et al., the antioxidant activities for the skin extracts of seven red and seven white grape varieties were determined by DPPH and FRAP[1]. Farhadi et al. detected antioxidant activity in different tissues of five native grape cultivars in Iran by DPPH and others methods [17]. The results by three methods accordantly showed that seeds were the highest in antioxidant activity followed by skins, and then pulp. Previous studies also indicated the same pattern [18].

\section{Conclusion}

In present study, expect TMAC was not be detected in seeds, and our results showed that seeds were the highest in polyphenol content and antioxidant activity followed by skins, and then pulp. Besides, 'Fenghou' is richer in polyphenolic content than other three cultivars. Hence, 'Fenghou' possesses stronger free radical scavenging ability.

\section{References}

1. V. Katalinić, SS. Možina, D. Skroza, I. Generalić, H. Abramović, M. Miloš, I. Ljubenkov, S. Piskernik, I .Pezo, P. Terpinc, M. Boban. Polyphenolic profile, antioxidant properties and antimicrobial activity of grape skin extracts of 14 Vitis vinifera varieties grown in Dalmatia (Croatia). Food Chem 119,715723(2010).

2. L.P. Santos, D.R. Morais, N.E. Souza, S.M. Cottica, M. Boroski, J.V. Visentainer. Phenolic compounds and fatty acids in different parts of Vitis labrusca and V. vinifera grapes. Food Res Int 44:14141418(2011).

3. J.F. Meng, Y.L. Fang, M.Y. Qin, X.F. Zhuang, Z.W .Zhang. Varietal differences among the phenolic profiles and antioxidant properties of four cultivars of spine grape (Vitis davidii Foex) in Chongyi County (China). Food Chem 134:20492056(2012).

4. I. Lee, S. Im, C.R. Jin, H.J. Heo, Y.S. Cho, M.Y. Baik, D.O. Kim. Effect of maturity stage at harvest on antioxidant capacity and total phenolics in kiwifruits (Actinidia spp.) grown in Korea. Hortic Environ Biotechnol 56(6):841-848(2015).

5. J. Dai, R.J. Mumper. Plant phenolics: Extraction, analysis and their antioxidant and anticancer properties. Molecules 15(10): 7313-7352(2010).

6. V.L. Singleton, J.A. Rossi. Colorimetry of total phenols with phosphomolybdic phosphotungstic acid reagents. Am J Enol Vitic 16: 144-158(1965).

7. Z.S. Jia, M.C. Tang, J.M. Wu. The determination of flavonoid contents in mulberry and their scavenging effects on superoxide radicals. Food Chem 64(4): 555-559(1999).

8. Y.G. Li, G. Tanner, P. Larkin The DMACA-HCl protocol and the threshold proanthocyanidin content for bloat safety in forage legumes. J Sci Food Agric 70(1): 89-101(1996).

9. X.Q. Wang, C.Y. Li, D. Liang, Y.J. Zou, P.M. Li, F. Ma. Phenolic compounds and antioxidant activity in red-fleshed apples. J Funct Foods 18: 10861094(2015).

10. W. Brandwilliams, M.E. Cuvelier, M.E. Berset. Use of a free-radical method to evaluate antioxidant activity. Food Sci Technol 28(1):25-30 (1995).

11. R. Re, N. Pellegrini, A. Proteggente, A. Pannala, M. Yang, C. Rice-Evans. Antioxidant activity applying an improved ABTS radical cation decolorization assay. Free Radical Bio Med 26(9-10): 12311237(1999).

12. I.F.F. Benzie, J.J .Strain. The ferric reducing ability of plasma (FRAP) as a measure of "antioxidant power": The FRAP assay. Anal Biochem 239(1): 70-76(1996).

13. Y. Yilmaz, Z. Göksel, S.S. Erdoğan, A. Öztürk, A. Atak, C. Özer. Antioxidant activity and phenolic content of seed, skin and pulp parts of 22 grape (vitis vinifera 1.) cultivars (4 common and 18 registered or candidate for registration). J Food Proces Preser 39: 1682-1691(2015).

14. Y.X. Xu, S. Burton, C. Kim, E. Sismour. Phenolic compounds, antioxidant, and antibacterial properties of pomace extracts from four Virginia-grown grape varieties. Food Sci Nutr 4(1):125-133 (2016).

15. J.F. Meng, Y.L. Fang, M.Y. Qin, X.F. Zhuang, Z.W. Zhang. Varietal differences among the phenolic profiles and antioxidant properties of four cultivars of spine grape (Vitis davidii Foex) in Chongyi County (China). Food Chem 134:2049-2056(2012).

16. K. Farhadi, F. Esmaeilzadeh, M. Hatami, M. Forough, R. Molaie. Determination of phenolic compounds content and antioxidant activity in skin, pulp, seed, cane and leaf of five native grape cultivars in West Azerbaijan province, Iran. Food Chem 199: 847- 855(2016).

17. M. Lutz, K. Jorquera, B. Cancino, B. Ruby, C. Henriquez. Phenolics and antioxidant capacity of table grape (Vitis vinifera L.) cultivars grown in Chile. J Food Sci 76: C1088-C1093 (2011). 